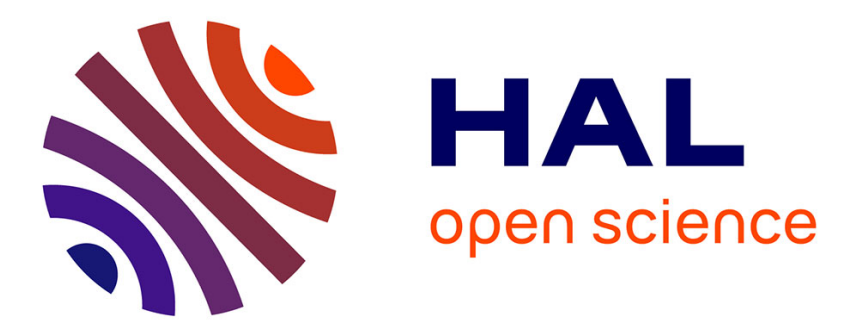

\title{
Deep sea immunity: Unveiling immune constituents from the hydrothermal vent mussel
}

Raul Bettencourt, Philippe Roch, Sergio Stefanni, Domitíla Rosa, Ana Colaço, Ricardo Serrão Santos

\section{- To cite this version:}

Raul Bettencourt, Philippe Roch, Sergio Stefanni, Domitíla Rosa, Ana Colaço, et al.. Deep sea immunity: Unveiling immune constituents from the hydrothermal vent mussel. Marine Environmental Research, 2007, 64 (2), pp.108. 10.1016/j.marenvres.2006.12.010 . hal-00501899

\section{HAL Id: hal-00501899 https://hal.science/hal-00501899}

Submitted on 13 Jul 2010

HAL is a multi-disciplinary open access archive for the deposit and dissemination of scientific research documents, whether they are published or not. The documents may come from teaching and research institutions in France or abroad, or from public or private research centers.
L'archive ouverte pluridisciplinaire HAL, est destinée au dépôt et à la diffusion de documents scientifiques de niveau recherche, publiés ou non, émanant des établissements d'enseignement et de recherche français ou étrangers, des laboratoires publics ou privés. 


\section{Accepted Manuscript}

Deep sea immunity: Unveiling immune constituents from the hydrothermal vent mussel Bathymodiolus azoricus

Raul Bettencourt, Philippe Roch, Sergio Stefanni, Domitíla Rosa, Ana Colaço, Ricardo Serrão Santos

PII:

S0141-1136(07)00005-0

DOI: 10.1016/j.marenvres.2006.12.010

Reference: MERE 3090

To appear in:

Marine Environmental Research

Received Date: $\quad 27$ September 2006

Revised Date: $\quad 20$ December 2006

Accepted Date: $\quad 28$ December 2006

Please cite this article as: Bettencourt, R., Roch, P., Stefanni, S., Rosa, D., Colaço, A., Santos, R.S., Deep sea immunity: Unveiling immune constituents from the hydrothermal vent mussel Bathymodiolus azoricus, Marine Environmental Research (2007), doi: 10.1016/j.marenvres.2006.12.010

This is a PDF file of an unedited manuscript that has been accepted for publication. As a service to our customers we are providing this early version of the manuscript. The manuscript will undergo copyediting, typesetting, and review of the resulting proof before it is published in its final form. Please note that during the production process errors may be discovered which could affect the content, and all legal disclaimers that apply to the journal pertain. 
Deep sea immunity: unveiling immune constituents from the hydrothermal vent mussel Bathymodiolus azoricus.

Raul Bettencourt ${ }^{*}$, Philippe Roch ${ }^{1}$, Sergio Stefanni, Domitíla Rosa, Ana Colaço, Ricardo Serrão Santos

IMAR/Department of Oceanography and Fisheries, University of the Azores, 9901862 Horta, Portugal

1) UMR CNRS EcoLag, University of Montpellier 2, case courrier 093, F-34095 Montpellier, France

*Correspondence:

Raul Bettencourt, $\mathrm{PhD}$

University of the Azores

Department of Oceanography and Fisheries

Genetics and Molecular Laboratory

Rua Comendador Fernando da Costa.

9900-862 Horta

Portugal

Tel: +351-292200400

Fax: +351-292200411

Email: raul@notes.horta.uac.pt

Key Words: innate immunity, transcription factor NF- $\kappa B$, antibacterial response, deep sea, hydrothermal vent, Bivalve, Bathymodiolus azoricus

Running title: Innate immunity in hydrothermal vent mussel 


\title{
ACCEPTED MANUSCRIPT
}

\begin{abstract}
Marine molluscs are subjected to constant microbial threats in their natural habitats. As a result, they represent suitable models for the study of the molecular mechanisms that govern defense reactions in marine organisms. To understand humoral and cellular defense reactions in animals defying extreme physical and chemical conditions we set out to investigate the deep sea hydrothermal vent mussel Bathymodiolus azoricus found in abundance at the Mid-Atlantic-Ridge. In the present study, hemocytes were stimulated with compounds of microbial origin and cellular morphological alterations as well as the production of superoxide assessed. Consequently, zymosan, glucan and peptidoglycan were considered as potent inducers of cellular reactions for inducing drastic cell morphology changes and high levels of superoxide production. Furthermore, we have presented for the first time in a deep sea hydrothermal vent animal, molecular evidence of the Rel-homology domain, a conserved motif present in all members of the Rel/nuclear-factor NF- $\kappa B$ family. Additionally we have demonstrated the occurrence of the antibacterial gene mytilin in Bathymodiolus azoricus gill tissues. Our results support the premise of an evolutionary conserved innate immune system in Bathymodiolus. Such system is seemingly homologous to that of Insects and other Bivalves and may involve the participation of $\mathrm{NF}-\mathrm{KB}$ transcription factors and antibacterial genes.
\end{abstract}




\section{Introduction}

Ancestral metazoans rely on innate immune mechanisms to eliminate infectious microorganisms. Their survival is thus ensured through efficient recognition of microbes and the subsequent activation of host mechanisms that involve cell-mediated and humoral reactions. Additionally, most invertebrates are equipped with a thick cuticle that acts as a first line of defense, somewhat like human skin or a physical barrier that excludes pathogens from entering the host. If the cuticle is breached allowing pathogen entry, sensitive recognition of microbial surface elements commonly referred as pathogen associated molecular patterns (PAMPs) will incur, followed by a rapid activation of cellular effectors such as circulating hemocytes or macrophage-like cells, and by the participation of humoral factors with antimicrobial, cytotoxic properties or with opsonin-like properties, facilitating phagocytosis reactions.

Insects, Molluscs and Crustaceans are emerging as suitable genetic and molecular models for the study of innate immune reactions (Leclerc and Reichhart, 2004; Gross et al., 2001; Bachère et al., 2004). Many gene products and signaling pathways share striking similarities between Mammals and Invertebrate innate immune reactions suggesting conserved mechanisms in the course of which, evolution privileged those responsible for the induction and transcriptional control of immune genes (Hoffmann and Reichhart, 2002). Perhaps the best example is the Toll receptor, first discovered and characterized in Drosophila and more recently in Mammals. Protein members of the transcription factor NF-kappaB family share a highly conserved 300 amino acids domain named the Rel homology domain (RHD). The RHD is essential for DNA binding and its function is important for the transcription of immune or inflammatory genes (Baltimore and Beg, 1995). NF-אB transcription factor homologues have been 
extensively studied in insects and recently characterized in molluscs (Montagnani et al., 2004). Internal defense in bivalve molluscs is essentially based on innate reactions involving a variety of cell types and effector molecules of which phagocytic hemocytes (blood cells) and degradative, oxidative enzymes and the generation of highly reactive oxygen intermediates (ROIs) play a prominent role in the defense against pathogens (Wootton and Pipe, 2003). While general immune reactions comprise potent reactive oxygen intermediates (ROIs) and antimicrobial agents to eliminate or neutralize infectious microorganisms (Anderson, 1994) some bivalve species do not appear to generate oxygen metabolites and in some studies, there is evidence suggesting a high inter-species variability of ROIs production (Lopez et al., 1994; Wooton and Pipe, 2003; Wootton et al., 2003). In addition, cell-free hemolymph possesses several biological peptides active against bacterial infection (Hubert et al., 1996a; Charlet et al., 1996) and soluble lectins with agglutinin properties (Wootton and Pipe, 2003; Wootton et al., 2003).

Oysters, Crassostrea genera and mussels, Mytilus genera are among the most intensively studied bivalves clearly for reasons concerning their economical importance, the environmental monitoring of pollutants and the prevention and spread of invertebrate diseases and human pathogens. Understanding how their biological systems cope with microbial infestation represents the opportunity to study and provide new insights into the basic physiological principles that govern the defense mechanisms in Molluscs.

Bivalve molluscs are found in abundance dwelling around deep sea hydrothermal vent sites. In the present case-study they are located near the Mid-Atlantic Ridge in the Azores region. Their physiological adaptation to extreme physical and chemical conditions raises interesting biological questions. Deep sea hydrothermal vent 
environments are considered highly toxic according to usual life standards, yet the animals subsisting at the vent sites exhibit high productivity and therefore must efficiently cope and tolerate unusual levels of heavy metals, $\mathrm{pH}$, temperature, $\mathrm{CO} 2$ and sulfide, in addition to environmental microbes (Santos et al., 2003). The problem of microbial threat and the need for immunity exist in both deep sea and shallow water bivalves however differences in the genes of marine organisms living in so distinct habitats are likely to occur.

In a first attempt to understand how the extreme physical and chemical conditions to which vent mussels have adapted can affect their host defense reactions, we set out to identify, components of an innate immune system in Bathymodiolus azoricus. The present report reveals for the first time the presence of a putative Rel Homology Domain (RHD) containing gene identified in gills and antibacterial genes such as mytilin in Bathymodiolus azoricus. Additionally, the laboratory set up to which vent mussels were acclimatized was regarded as a suitable and amenable system to study hemocyte reactions even in the absence of the characteristic high hydrostatic pressure found at deep sea vent sites. We proposed that Bathymodiolus azoricus is equipped with evolutionary conserved immune factors commonly found in other marine bivalves. Moreover, our results provide molecular tools that can be applied to evaluate the effect of extreme environmental factors on host immune reactions in deep sea hydrothermal vent mussels. 


\section{Methods and Materials}

\subsection{Animal collection and tissue preparation}

Mussels were collected using the French ROV Victor 6000 (R/V Atalante, IFREMER) during the EXOMAR cruise (July $27^{\text {th }}$ - August $2^{\text {nd }} 2005$ ) from the Lucky Strike $\left(37^{\circ} 13.52^{\prime} \mathrm{N}, 32^{\circ} 26.18^{\prime} \mathrm{W} ; 1700 \mathrm{~m}\right.$ depth) hydrothermal vent site, in the vicinity of the Mid Atlantic Ridge (MAR). Once the mussels were brought to the surface, they were immediately processed onboard or left in fresh cooled seawater for subsequent manipulation and acclimatization in the Azorean land-based hydrothermal vent laboratory set up, LabHorta (Colaço et al., 2003). For the maintenance of Bathymodiolus azoricus under post-capture conditions, physical and chemical parameters were essentially followed as described in Kaddar et al. (2005). For comparative studies, the clam Ruditapes decussatus was collected from the coastal lagoon on São Jorge Island in the Azores and the mussel Mytilus galloprovincialis was obtained from a shellfish farm in southern France. The hard clam Mercenaria mercenaria was obtained from a local hatchery in Long Island, New York. Both $M$. galloprovincialis and M. mercenaria tissues were processed during R.B visits to Prof Philippe Roch (University of Montpellier, France) and to Dr Bassem Allam (Marine Science Research Center, SUNY Stony Brook, USA) laboratories, respectively. Gill tissues were either preserved for histological observations according to standard protocols using $5 \%$ formalin and $70 \%$ Ethanol solutions or used fresh in addition to hemocytes, in conformity with cellular studies and antibacterial assays. 


\subsection{Hemocyte reactions and Antibacterial assays}

Hemolymph was withdrawn from B. azoricus by introducing a syringe through the posterior adductor muscle and deposited directly onto a sterile microscope glass slide. To each slide containing approximately $100 \mu$ l of hemolymph, an additional $20 \mu \mathrm{l}$ of distinct commercially available pathogen associated molecular pattern (PAMPs) suspensions $(10 \mu \mathrm{g} / \mathrm{ml})$ were added and covered with a cover slip. Slides were kept in a humid chamber for $15 \mathrm{~min}$ and hemocyte reactions observed under light microscopy. The following PAMPs suspensions of microbial origin, were used in a similar procedure as described in Bettencourt et al. (2004): Zymosan (a carbohydrate derivative from the yeast cell wall of Saccharomyces cerevisiae, Sigma Z 4250), $\beta$-1,3-glucan (a polysaccharide extracted from the cell wall of the seaweed algae Laminaria digitata, Sigma L-9634), Peptidoglycan (a polymer consisting of carbohydrate and amino acids from the bacterial cell wall of Staphylococcus aureus, Fluka 77140), Lipopolysaccharide (also known as bacterial endotoxin LPS, a major molecule of cell membrane from gramnegative bacteria, consisting of a lipid and a polysaccharide,, extracted from Escherichia coli 055:B5, Sigma L-4524),. In addition, $10 \mu \mathrm{M}$ phorbol-12-myristate-13-acetate (known as PMA, a human lymphocyte proliferation inducer, Sigma P-8139) diluted in phosphate buffer saline was used in incubations with freshly withdrawn hemolymph.

The generation of superoxide $\left(0_{2}^{-{ }^{\circ}}\right)$ by hemocyte suspensions was monitored according to the procedures of Anderson et al. (1994) and Arumugam et al. (2000) with minor modifications. Briefly, an aliquot of $1 \mathrm{ml}$ hemocyte suspension in sterilized sea water (containing $10^{8}$ cells $/ \mathrm{ml}$ ) was incubated with an equal volume of $0.1 \%$ of Nitro blue tetrazolium chloride (NBT), with or without chemicals of microbial origin (100 $\mu 1$ of the following, $1 \mathrm{X}$ yeastolate (a yeast extract, Invitrogren $\left.{ }^{\circledR}\right)$, zymosan $(10 \mathrm{mg} / \mathrm{ml})$, glucan 
(10 mg/ml), peptidoglycan (10mg/ml), Lipopolysaccharide (LPS) $(10 \mathrm{mg} / \mathrm{ml})$ and PMA $(10 \mu \mathrm{M})$, at room temperature and for $60 \mathrm{~min}$. Control experiment consisted of incubations with sterilized sea water. After centrifugations and resuspensions described in Arumugam et al. (2000), the optical density of supernatants obtained from controls and stimulated hemocytes were read at $630 \mathrm{~nm}$ from four independent experiments.

For antibacterial assays, whole gill and hemocyte homogenates from B. azoricus were prepared with Phosphate Buffer saline containing proteases inhibitors (Sigma ${ }^{\circledR}$, Protease inhibitor cocktail P2714) and tested in agar based Luria-Bertani medium plates overlaid with a bacterial-agar lawn (0.7\% top agar layer). Bacterial growth-inhibition assays were carried out with one of the following bacterial strains $\left(1 \times 10^{7} \mathrm{cfu} / \mathrm{ml}\right)$ : Micrococcus luteus, Enterobacter cloacae, Escherichia coli, Pseudomonas aeruginosa, Bacillus subtilis and Staphylococcus aureus.

\subsection{RNA extraction, Reverse Transcription-Polymerase Chain Reaction and sequencing}

Total RNA from Bathymodiolus azoricus gill tissues was extracted with

TRIZOL (Life Technology ${ }^{\circledR}$ ) according to manufacturer's instructions and re-suspended in nuclease-free water. The quality of total RNA preparations was assessed in agarose gel electrophoresis using the standard denaturing formaldehyde procedure. For the first strand cDNA synthesis or reverse transcriptase reaction (RT), the Moloney Murine Leukemia Virus (M-MLV) reverse transcriptase enzyme (Promega) was utilized according to manufacturer's instructions and using $5 \mu \mathrm{g}$ total RNA in $50 \mu$ l total volume reactions containing RNAse inhibitor. Subsequently, $5 \mu 1$ of RT reactions were mixed to a Polymerase Chain Reaction (PCR) master mix (PCR Master Mix, Promega ${ }^{\circledR}$ ) containing appropriate PCR buffer, deoxyribonucleotide triphosphates (dNTPs) 
$(10 \mathrm{mM})$, Taq polymerase and degenerated or sequence-specific oligonucleotides as primers to target immune-related genes from $B$. azoricus. In order to identify members of the inflammatory transcription factor Rel/NF- $\kappa$ B gene family, the Rel homology domain (RHD), was chosen for its conserved DNA binding domain sequence homology among different taxonomic groups. Thus, multiple sequence alignments retrieved from the Protein families data base of alignments (Pfam) web site based at the Sanger Institute, UK (http://www.sanger.ac.uk/Software/Pfam/index.shtml) were selected for the design of degenerated primers. The aligned sequences included RHDs from Drosophila melanogaster, Crassostrea gigas, Strongylocentrotus purpuratus, and Halocynthia roretzi. The sense degenerated primer was based on the amino acid sequence RFRYECE and corresponded to: 5'-MGNTTYMGNTAYGARTGYGAR-3'. The antisense degenerated primer was based on the amino acid sequence VVRLCFQ and corresponded to: 5'-YTGRAARCANARNCKNACNAC-3'. Both primers were manufactured by INVITROGEN using the following IUB codes to identify nonstandard or mixed bases: $\mathbf{M}=\mathrm{A}+\mathrm{C} ; \mathbf{K}=\mathrm{T}+\mathrm{G} ; \mathbf{R}=\mathrm{A}+\mathrm{G} ; \mathbf{N}=\mathrm{A}+\mathrm{C}+\mathrm{G}+\mathrm{T} ; \mathbf{Y}=\mathrm{C}+\mathrm{T}$.

Sequence-specific primers for DNA amplification of the Rel domain in $B$. azoricus was determined after successful sequencing of PCR products obtained in RTPCR experiments using Mytilus galloprovincialis RNA and the above mentioned degenerated primers. The RHD sequence-specific sense primer was: 5'TATGAGTGCGAGGGAAGATCT-3' and the RHD sequence-specific anti-sense primer was: 5'-GAAAGGGTCAACGTTGATTTC-3'. Thermocycling conditions were performed taking in account primer's degeneracy and lower annealing temperatures. Thus, a $50 \mu \mathrm{l}$ volume reaction containing $5 \mu \mathrm{l}$ of RT product, $4 \mu \mathrm{l}$ of the sense and antisense primers (total of $80 \mathrm{pmol}$ each), $5 \mu \mathrm{l}$ of $25 \mathrm{mM} \mathrm{MgCl}_{2}, 5 \mu \mathrm{l}$ of 10X PCR enhancer solution (Invitrogen), $6 \mu$ l of PCR grade water and $25 \mu 1$ of 2X PCR Mix (Promega ${ }^{\circledR}$ ) 
was subjected to the following thermocycling conditions: Initial denaturing step at $94^{\circ} \mathrm{C}$ for $2 \mathrm{~min}$, followed by 10 cycles of denaturation at $94^{\circ} \mathrm{C}$ for $1 \mathrm{~min}$, annealing at $48^{\circ} \mathrm{C}$ for $2 \mathrm{~min}$ and extension at $70^{\circ} \mathrm{C}$ for $1.30 \mathrm{~min}$. Subsequently, cycling reactions followed another round of 35 cycles of denaturation at $94^{\circ} \mathrm{C}$ for $30 \mathrm{sec}$, annealing at $52^{\circ} \mathrm{C}$ for 1 min and extension at $70^{\circ} \mathrm{C}$ for $1 \mathrm{~min}$. PCR reaction terminated with a final extension at $70^{\circ} \mathrm{C}$ for $10 \mathrm{~min}$. When using sequence-specific RHD primers thermocycling conditions were slightly different: Initial denaturing step at $94^{\circ} \mathrm{C}$ for $2 \mathrm{~min}$, followed by 10 cycles of denaturation at $94^{\circ} \mathrm{C}$ for $1 \mathrm{~min}$, annealing at $52^{\circ} \mathrm{C}$ for $1 \mathrm{~min}$ and extension at $70^{\circ} \mathrm{C}$ for $1 \mathrm{~min}$. Cyclic reactions followed another round of 25 cycles of denaturation at $94^{\circ} \mathrm{C}$ for $30 \mathrm{sec}$, annealing at $56^{\circ} \mathrm{C}$ for $30 \mathrm{sec}$ and extension at $70^{\circ} \mathrm{C}$ for $30 \mathrm{sec}$. PCR reaction ended with a final extension at $70^{\circ} \mathrm{C}$ for $10 \mathrm{~min}$. PCR products were examined on $1.5 \%$ agarose gel electrophoresis using Tris-boric acid-EDTA buffer and ethidium bromide for DNA visualization, according to standard protocol. 1 KB Plus DNA ladder (Invitrogen) was used as a marker. To identify RHD cDNA in Ruditapes decussatus and Mercenaria mercenaria, similar experimental approach was used as described above.

In an attempt to target antibacterial genes in B. azoricus we also used sequencespecific primers based on Mytilus galloprovincialis mytilin and defensin MGD2 genes in RT-PCR experiments. The mytilin sense and anti-sense primers were: 5' GTTATTCTGGCTATCGCTCTTG ${ }^{3}$, and ${ }^{5}$ 'GTATAATGTCAAACAGAACGGGTC ${ }^{3}$, respectively. The defensin MGD2 sense and anti-sense primers were:

${ }^{5}$ CAGCATtCGTCTtGTtGGtGG ${ }^{3}$ ' and ${ }^{5}$ 'CGCATCTATAGCATGTGCACC ${ }^{3}$ ', respectively. All PCR amplicons were gel extracted with the Wizard SV GEL and PCR Clean-Up System (Promega), re-suspended in double distilled $\mathrm{H}_{2} \mathrm{O}$ and submitted to nucleotide sequencing with both sense and anti-sense primers, through the BMRGenomics sequencing facility at the University of Padova, Italy (http://www.bmr- 
genomics.it/). Database sequence homology searches were performed with the Webbased BLAST search tool available at: http://www.ncbi.nlm.nhi.gov. RHD sequences were submitted to GenBank (National Center for Biotechnology Information, Bethesda MD) and given the following accession references: Bathymodiolus azoricus RHD, DQ673621; Mercenaria mercenaria RHD, DQ673622; Mytilus galloprovincialis RHD, DQ673623 and Ruditapes decussatus RHD, DQ673624.

\subsection{Amino acid alignment and phylogenetic analysis}

The predicted RHD amino acid sequences from Bathymodiolus azoricus, Mytilus galloprovincialis, Ruditapes decussatus and Mercenaria mercenaria were compared to other RHD amino acid sequences from Tubifex tubifex GenBank accession No BAD60879; Drosophila melanogaster GenBank accession No AAT94434, Halocynthia roretzi GenBank No BAD47173, Danio rerio GenBank accession No AA026402, Xenopus laevis GenBank accession No AAH70711 and Homo sapiens GenBank accession No AAH11603. Complete alignment was performed with CLUSTAL X (Thompson et al., 1997) with the following changes to the default values: gap opening penalty $=35.00$ and gap extension penalty $=0.75$ in the pairwise alignment parameters; and gap opening penalty $=15.00$ and gap extension penalty $=0.30$ in the multiple alignment parameters.

The phylogenetic tree of the RDH amino acid sequences was constructed using MEGA version 3.1 (Kumar et al., 2004). The neighbor-joining (NJ) algorithm (Saitou and Nei, 1987) was implemented to construct a phylogenetic tree from the Poisson correction distances (Nei and Kumar, 2000). The support for internal branches within the NJ tree was assessed using the bootstrap (Felsenstein, 1985) with 1000 replicates. 


\subsection{Whole mount and paraffin tissue sections in-situ hybridization}

Single gill filaments were separated from formalin-70\% Ethanol preserved gill tissues from B. azoricus and analyzed for the presence of Rel/NF- $\kappa \mathrm{B}$ and mytilin transcripts according to Tautz (1996) and Braissant \& Wahli (1998) with minor modifications. Since filaments were originally fixed, a pre-treatment step was carried out with Phosphate Buffered Saline (PBS) containing 0.1\% Triton X 100 for $15 \mathrm{~min}$ at room temperature after which a mild treatment with PBS containing $50 \mu \mathrm{g} / \mathrm{ml}$ of proteinase $\mathrm{K}$ was performed for $5 \mathrm{~min}$ at room temperature. The proteinase $\mathrm{K}$ digestion time is critical for subsequent steps since filaments are made up of two coalescent unicellular layers of endothelial-like cells. After proteinase K digestion, filaments were washed thoroughly with PBS containing $0.1 \%$ Triton X 100 and re-fixed for 15 min with 4\% paraformaldehyde in PBS. Two subsequent washes were performed with PBSTriton $\mathrm{X}$ solution and finally filaments were equilibrated with $5 \mathrm{X}$ SSC $(\mathrm{NaCl} 0.75 \mathrm{M}$, Na-Citrate $0.075 \mathrm{M}$ ) before pre-hybridization. Pre-hybridization was carried out as described in Braissant \& Wahli (1998) for 6 hours at $55^{\circ} \mathrm{C}$ after which the hybridization reaction was performed at $55^{\circ} \mathrm{C}$ for 16 hours. A PCR-generated probe corresponding to RHD (see above) was biotinylated (Biotin-High Prime, Roche Diagnostics) and used to detect Rel/NF- $\kappa B$ messengers (mRNA). In addition, a cDNA probe corresponding to mytilin was generated by PCR, biotinylated and used to target the antibacterial gene mytilin. After hybridization, filaments were washed for $30 \mathrm{~min}$ in $2 \mathrm{X} \mathrm{SSC}$, at room temperature, 2 times $30 \mathrm{~min}$ in $2 \mathrm{X} \mathrm{SSC}$ at $55^{\circ} \mathrm{C}$ and 2 times $30 \mathrm{~min}$ in $0.1 \mathrm{X} \mathrm{SSC}$ at 55 ${ }^{\circ} \mathrm{C}$. Filaments were then equilibrated in (buffer 1) $100 \mathrm{mM}$ Tris- $\mathrm{HCl}, 150 \mathrm{mM} \mathrm{NaCl}, \mathrm{pH}$ 7.5 for $15 \mathrm{~min}$ and incubated with the same buffer containing streptavidin-alkaline 
phosphatase conjugate (Roche Diagnostics) diluted 1:5000 and 1\% blocking reagent (Roche Diagnostics) for 6 hours or over night. After thorough washes with buffer 1, an additional incubation was performed with (buffer 2) $100 \mathrm{mM}$ Tris-HCl, $100 \mathrm{mM} \mathrm{NaCl}$ and $50 \mathrm{mM} \mathrm{MgCl}_{2}, \mathrm{pH}$ 9.5. Color development was performed at room temperature in buffer 2 containing $0.02 \%$ BCIP and $0.03 \%$ NBT. The resulting color may vary depending on the amount of transcript but visualization was typically detected in $B$. azoricus gills within 1-3 hours. Control experiments were carried out using an unrelated PCR generated 300 bp cDNA fragment (calf thymus gene, Clontech) labeled with Biotin-High Prime (Roche Diagnostics). To detect and localize specific Rel/NF- $\kappa$ B and mytilin mRNAs in paraffin-embedded tissue sections, gill tissues were preserved according to standard histological procedures using an automated tissue processor (LEICA TP 1020) and sectioned with a manual microtome (LEICA RM 2035). Prehybridization and hybridization were as mentioned above for whole mount tissues experiments.

\section{Results}

\subsection{Cellular reactions an antibacterial assays}

In the present study we subjected freshly withdrawn hemolymph from $B$. azoricus to sterile sea water solutions containing different purified compounds of microbial origin (pathogen-associated molecular patterns, PAMPs). These compounds have been utilized as inducers of innate immune reactions in different taxonomic groups. Stimulation of hemocytes present in the hemolymph was clearly induced as morphological changes such as philopodia extensions and degranulation were observed 
during exposures to zymosan, $\beta$-glucan or peptidoglycan whereas lipopolysaccaride (LPS) and phorbol myristate acetate (PMA) did not have a visible effect on cell morphology (Fig 1A). The apparent lack of responsiveness to PMA stimulation is somewhat intriguing as this molecule is a well known stimulant of Protein Kinase C activity in immune competent cells of mammalian and invertebrate systems. To further investigate the hemocyte activation as a result of exposure to immune inducers, we assessed the production of superoxide by means of a colorimetric assay based on the reduction of nitro blue tetrazolium and the formation of formazan. The gram ${ }^{+}$bacterial cell wall component, peptidoglycan and yeast derivatives such as zymosan and glucan did induce high levels of free oxygen radicals. In contrast, such induction was markedly reduced when LPS and PMA were used (Fig. 1B). Thus, the cellular morphological alterations visualized with zymosan, glucan and peptidoglycan seemed to compare with the elevated levels of $\mathrm{O}_{2}^{-{ }^{-}}$produced. Although no obvious morphological changes could be visualized with LPS and PMA, their effect on the superoxide production was clearly above the levels obtained in control experiments (Fig 1B).

To test antibacterial activity in gill and hemocytes extracts, we used LB agar plates overlaid with an agar bacterial lawn. Antibacterial activity was observed in both gill and hemocyte extracts only against the gram-positive bacteria $M$. luteus, whereas activity against $B$. subtilis and E. cloacae was observed only in gill extracts. Both extracts did not present activity against E. coli, S. aureus and P. aeroginosa (Fig. 2).

The reduced growth inhibition zone when using twice the amount of M. luteus on bacterial plates indicates that the amount of bacteria could be a limiting factor of antibacterial activity. 


\subsection{Immune genes transcripts in gill tissues}

Given the strategic significance that gill tissues take on as filtering interfaces between the external milieu and the animal's body cavity, it is presumed that the presence of immune genes should be prevalent where host tissue organisms meet foreign microorganisms. Therefore, we set out to investigate the expression of Rel/NF$\mathrm{B}$ and antibacterial genes in gill tissues. RT-PCR analyses of total gill RNA were performed with degenerated primers aimed at DNA amplification of the Rel Homology Domain (RHD) given its remarkable amino acid sequence conservation between invertebrates and mammals transcription factors of the Rel/NF- $\kappa B$ family. Successful cDNA amplifications were obtained with Mytilus galloprovincialis RNA after which their nucleic acid sequence information was used as a basis for the design of sequencespecific primers to re-amplify the same RHD domain. Specific primers were tested on all gel extracted and purified candidate cDNA products (320-350 bp) obtained in previous degenerated-primers based PCR experiments. Accordingly, PCR products resulted in single amplicons (300-320 bp) (Fig 3). They were then, subjected to further sequencing analyses. All putative 300-320 bp RHD cDNA sequences from Bathymodiolus azoricus, Mytilus galloprovincalis Ruditapes decussatus and Mercenaria mercenaria matched the oyster Crassostrea gigas transcription factor Rel 1 and Rel 2 to a high degree of amino acid sequence identity (above 80\%) when conceptually translated. Other homology matches included RHD amino acid sequences from annelids and insects (Fig. 4A and B)

Sequences alignments indicate that the RHD is well conserved among the organisms considered for the phylogenetic analysis (Fig 4A). Mytilidae (Bathymodiolus 
and Mytilus) and Veneridae (Mercenaria and Ruditapes) species seem more related to one another when compared to Ostreidae (Crassostrea) which distances itself from the bivalves analyzed (Fig 4B). These results seem to suggest that the organisms tested in our study are equipped, as their bivalve relative $C$. gigas, with a signaling pathway similar to that of mammalian Rel/NF-kB.

We also carried out experiments, using sequence-specific primers based on Mytilus galloprovincialis antibacterial genes, mytilin and defensin MGD2. Whereas cDNA sequences (200 bp) obtained with defensin primers could not be related to Mytilus defensin gene (data not shown), mytilin primers on the other hand, clearly targeted the B. azoricus mytilin gene during RT-PCR experiments (Fig 3). This constitutes the first experimental evidence in support of the presence of an antibacterial gene in tissues isolated from a deep-sea hydrothermal vent organism.

To further demonstrate the presence of immune genes in gill tissues we developed in-situ hybridization experiments taking advantage of the thin and coalescent unicellular-layers structure of single gill filaments. NF- $\mathrm{\kappa B}$ and mytilin transcripts were clearly observed in hemocytes located within the lumen of filaments and in cells located along the lateral face of the gill filaments (Figs 5 and 6). Specificity of our in-situ hybridization analyses was demonstrated in control experiments using irrelevant cDNA probes handled as in specific probe experiments aimed at targeting RHD containing messengers and mytilin gene. As a result, no specific messenger could be detected when control probes were used (Fig 5).

These findings are consistent with previous experimental data by Mitta et al., (2000) and Montagnani et al., (2004) in which the presence of mytilin and NF-kB have been demonstrated in Mytilus galloprovincialis and Crassostrea gigas, respectively. 


\section{Discussion}

In bivalve molluscs hemocytes are responsible for cell-mediated immunity through phagocytosis and cytotoxic reactions which may involve the generation of reactive oxygen intermediates (ROIs) and the release of lysosomal enzymes or antimicrobial peptides (Wootton et al. 2003; Hubert et al. 1996b). Nitric oxide and ROIs act inside the phagolyzosomes during phagocytosis and are too dangerous to be released into the circulation as for antimicrobial peptides (Gourdon et al., 2001). Furthermore, the hemolymph serum contains humoral defense factors, whether or not involved in direct elimination of pathogens, such as antibacterial peptides and soluble lectins that may function as opsonins facilitating phagocytosis. Bivalves are also known for their susceptibility to environmental pollutants and have been regarded as bio-indicators or surveillance organisms of aquatic pollution.

The hydrothermal vent mussel Bathymodiolus azoricus is commonly found in dense populations at the Mid Atlantic Ridge and appears to be well adapted to their peculiar environment. Other Bathymodiolid species are also found in dense communities associated with deep sea hydrothermal vents and cold-water sulfide/hydrocarbon seeps distributed in both the Atlantic and Pacific Oceans. This corroborates their functional adaptability to extreme environments (Von Cosel et al. 1999; Gustafson et al. 1998). The toxic chemical nature of vent surrounding is seemingly deleterious to the animals. Yet, amid fluids rich in sulfur compounds, methane, and high concentration of trace metals, these animals have developed successful strategies to cope with adverse physical and chemical environmental conditions as well as with elevated temperatures and hydrostatic pressure. 
To understand how hydrothermal vent mussels overcome microbial challenges in their natural surroundings we initiated a series of investigations aimed at the elucidation of host defense mechanisms in Bathymodiolus azoricus. Therefore, we first recognized constituents of an innate immune system and assessed the viability of vent mussels once acclimatized to laboratory conditions. Previous work conducted in our land hydrothermal vent laboratory has proven successful to ensure the survival of vent mussels for weeks or months. Consequently, we followed the same methane, sulfide and temperature settings as in Kadar et al. (2005). Even though animals were not submitted to similar hydrostatic pressure conditions as in vent sites, the hemocyte reactions that we observed were strongly evocative of other mollusc and insect hemocyte responses. Hemocytes responded well to known immune stimulants of microbial origin. The preponderance of hemocytes of the granulocyte type was constantly observed during our experiments when compared to the few hyalinocytes visualized. When stimulated with zymosan or $\beta$-glucan the reactions ensuing were usually rapid and incurred in immediate morphological changes, pseudopod extensions and degranulation of the hemocytes and in some circumstances followed by complete cellular lysis (Fig 1A). Under such experimental conditions, clumping of hemocytes were not visualized onto glass slides whereas freshly collected hemocytes left in suspension would aggregate in large clumps and settle at the bottom of collection tube (data not shown). On other occasions when animals were injected with a suspension of rehydrated sheep red blood cells, immediate aggregation of hemocytes could be observed in freshly withdrawn hemolymph, forming clusters together with the red blood cells (data not shown).

Hemocyte immune activation is typically accompanied by the production of toxic nitric oxide and oxygen free radicals as a means to deter or eliminate infectious microorganisms. In our study we observed the production of superoxide by 
Bathymodiolus azoricus hemocytes when exposed to chemicals of microbial origin. Stimulation with zymosan, glucan and peptidoglycan induced higher levels of $\mathrm{O}_{2}^{-{ }^{\circ}}$ production than LPS and/or PMA stimulation (Fig 1B). This is consistent with previous investigations demonstrating the role of fungal cell wall derivatives as immunomodulators (Vaseeharan et al. 2006; Campa-Cordova et al. 2002; Arumugam et al. 2000; Andersson et al. 1994). Thus, irrespective of the atmospheric pressure and laboratory setting to which vent mussels were acclimatized their hemocytes do not seem to differ from the cellular reactions seen in shallow water mussels when stimulated with conventional immunodulators. However, the absence of cellular morphological changes when LPS and/or PMA were used suggests that hemocyte activation in Bathymodiolus azoricus is manifested through different responses to non-self molecules and probably involving different signaling systems. Bivalve hemocytes have the ability to phagocytose foreign particles while generating cytotoxic molecules such as reactive oxygen intermediates (ROIs) including superoxide anions, hydrogen peroxide and nitric oxide (Arumugam et al., 2000). Furthermore, phagocytosis is also accompanied by cellular morphological changes clearly observed as hemocytes rapidly attach to glass slides and opsonized heat killed yeast are readily taken up (Arumugam et al., 2000). It remains to be investigated whether or not Bathymodiolus azoricus hemocytes have increased phagocytosis indexes in the presence of the immunomodulators used in our assays. It is also unknown which molecular mechanisms induce vent mussel hemocytes to generate superoxide in the presence of microbial constituents.

Anti-gram positive and anti-gram negative bacterial activities were clearly manifested in gill homogenates prepared from naive $B$. azoricus which is consistent with an inherent tissue-specific defensive role of filter feeding bivalves. During our experiments we also set out to investigate the presence of immune genes homologous to 
that of the oyster Crassostrea gigas and the mussel Mytilus galloprovincialis. As demonstrated by in-situ hybridization, RHD containing messengers were detected in hemocytes of gill filament tissues. Likewise, the discovery in B. azoricus of a cDNA sequence corresponding to the Rel Homology Domain is strongly suggestive of the

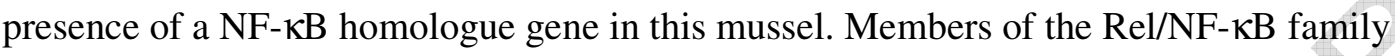
are cytoplasmic proteins that function as transcription factors. Upon extra cellular stimuli and ensuing intracellular signaling processes, transcription factors freed from their cytoplasmic IKB inhibitors, translocate into the nucleus where they form homo or heterodimer DNA associations with regulatory sequences ( $\kappa \mathrm{B}$ binding sites) in the promoter region of genes normally involved in inflammatory and innate immune reactions in both mammals and insects (Silverman and Maniatis, 2001).

Recently, the identification of $\mathrm{Cg}$-Rel, the first Rel/NF- $\kappa \mathrm{B}$ homologue characterized in a mollusc, the Pacific oyster Crassostrea gigas represents, thus far, an additional evidence for the evolutionary conservation of regulatory pathways that serve to regulate genes involved in innate immune defense (Montagnani et al. 2004). While Rel/NF- $\kappa \mathrm{B}$ activation leads to the transcription of antibacterial and antifungal genes in insects, the presence of a putative NF- $\mathrm{KB}$ homologue in Bathymodiolus azoricus cannot at this point be directly correlated to the finding of a putative mytilin gene in this mussel as demonstrated in our RT-PCR experiments and sequence of B. azoricus mytilin cDNA (Fig 3). The sequence identity of the conceptually translated B. azoricus mytilin cDNA is $100 \%$, which articulates well with the argument that a mytilin gene homologue is present in vent mussel gills.

In addition to the recent discovery of cg-Rel and other components of the NF- $\kappa \mathrm{B}$ signaling pathway in Crassostrea gigas, (Montagnani et al. 2004; Escoubas et al. 1999; Guéguen et al. 2003) our results suggest the existence in Bathymodiolus, of an innate 
immune system similar if not conserved to that of Crassostrea and Mytilus and other invertebrates. The localization of B. azoricus mytilin in gill filaments (Figs. 5 and 6) is of strategic significance as gill tissues are regarded as a port of entry for pathogens and represent natural barriers to environmental factors including microorganisms and pollutants. We have demonstrated that $B$. azoricus gill extracts exhibit antibacterial activity against several bacteria tested. Similarly, hemocyte extracts discernibly presented antibacterial activity but not against all the bacterial strains tested and in some cases only gills and not hemocytes extracts exhibited such activity (Fig 2). This seems to indicate the presence of more than one type of antibacterial activity located in gill tissues. We favor the possibility that this activity is attributed to the presence of hemocytes in gill filaments as demonstrated in our in-situ hybridization experiments (Figs. 5 and 6). However, it is not excluded that gill epithelial cells could have endogenous antibacterial properties as well.

Bathymodiolid mussels have recently been the subject of detailed studies involving heavy metal determinations in vent animal communities and studies concerning bacterial symbiosis in mussel gill bacteriocytes. The presence of chemoautotrophic and metanotrophic bacterial symbiont types in specialized epithelial cells of vent mussel gill tissues is believed to provide substantial nutritional advantage to the mussel, thus enhancing its aptitude to oxidize sulfide and methane at the vent sites (Duperron et al. 2006; Fiala-Médioni et al. 2002; Distel et al. 1995). Moreover, the ability of housing symbiotic intracellular bacteria appears to be a general feature throughout bivalves which have adapted very efficiently to living from organic matter originated from chemoautotrophic processes (Fiala-Médioni and Felbeck, 1990)

Yet, the mode of symbiont transmission to post-larval benthic mussels is not fully elucidated. From a host defense perspective, the symbiont transmission raises an 
interesting immunological challenge, in view of the fact that bacterial endosymbionts must avoid potential adverse reactions triggered by the mussel's innate defense at the time of acquisition in gill tissues. Interestingly, bacterial endosymbiont might exhibit mechanisms of immune recognition avoidance such as host cell surface mimicry or inhibition of host antibacterial responses, however these processes have not been characterized.

Nevertheless, the great number of endosymbionts found throughout the gill tissues of vent mussels seems to propose that the host defense mechanisms are unaware of the presence of bacterial symbionts while reacting in a defensive manner against other bacterial types. Alternatively, the endosymbiont bacteria could exhibit an antibacterial effect of their own, and interfere with the processes seen in the growth inhibition zone assays (Fig. 2). This possibility deserves further investigation since we used freshly collected endosymbiont-rich gill tissues. Therefore, similar antibacterial studies in our laboratory, are currently under investigations using endosymbiont depleted hydrothermal vent mussels maintained for long periods of time in plain sea water (with no additional nutrition supplement).

With respect to genotoxicity assessment in marine environments, Bathymodiolus azoricus could reveal interesting findings regarding gene expression analyses using Rel/NF- $\mathrm{KB}$ and antibacterial mytilin as target genes in comparative studies and evaluate the mussel immune responses to heavy metal exposure experiments. Thus, the vent mussel innate immune system could constitute an alternative, and perhaps a more sensitive approach, to discover genes potentially used to assess genotoxicity as opposed to the traditional techniques involving evaluation of tissue damage and injury 
assessment, deterioration of somatic and germ cells, genetic damage or the use of other bioassay organisms as surrogates for target species (Hose, 1994).

\section{Conclusion}

The biological significance of our findings validates the vent mussels as a genuine model organism for host-defense studies. It also introduces Bathymodiolus azoricus as an amenable model for the study of genes involved in physiological adaptations to the inhospitable physical and chemical conditions in which deep sea vent animals thrive. Experimental acclimatization of Bathymodiolus azoricus did not affect cellular reactions which were similar to those of shallower mussels from coastal regions. The presence of Rel domain containing messengers in hemocytes could indicate that $B$. azoricus is equipped with transcription factor members of the Rel/NF$\kappa \mathrm{B}$ family. Yet, cDNA products corresponding to the antibacterial gene mytilin constitutes another evidence that vent mussels possess an innate immune system akin to their shallow water mytilid relatives.

\section{Acknowledgements}

We thank Chief Scientist Anne Godfroy and the shipboard nautical, technical and scientific parties of the R/V Atalante/ROV VICTOR 6000 during the EXOMAR cruise for assistance in collection of samples. We are most grateful to Humberto Lopes and Valentina Costa for skillful laboratory assistance. We also thank Prof Philippe Roch and Dr Bassem Allam team members for supportive effort. This work was supported by funds provided by the network of Excellence MarBEF (Marine Biodiversity and 
Ecosystem Functioning-contract No. GOCE-CT-2003-505446); the research project SEHAMA from the Portuguese Foundation for Science and Technology (Seafloor and sub-seafloor hydrothermal modelling in the Azores Sea-PDCTM/P/MAR/15281/1999); the pluri-annual and programmatic funding scheme from the IMAR/DOP research unit \#531 and associate laboratory \#9; the Luso-American foundation FLAD (research project L-V-173/2006 granted to R.B) and the Regional Azorean Directorate for Science and Technology (DRCT). The Portuguese FCT post-doctoral fellowships SFRH/BDP/14896/2004 (R.B.) and SFRH/BPD/14981/2004 (S.S.) are gratefully acknowledged. We are also indebted to Ilda Bettencourt and Natalia Correia for proofreading of the manuscript and to the two anonymous reviewers for their helpful comments.

\section{References}

Anderson, R., 1994. Hemocyte-derived reactive oxygen intermediate production in four bivalve mollusks. Developmental \& Comparative Immunology 18, 89-96.

Arumugam, M., Romestand, B., Torreilles, J., Roch, P., 2000. In vitro production of superoxide and nitric oxide (as nitrite and nitrate) by Mytilus galloprovincialis heamocytes upon incubation with PMA or laminarin or during yeast phagocytosis. European Journal of Cell Biology 79, 513-519.

Bachère, E., Guéguen, Y., Gonzalez, M., de Lorgeril, J., Garnier, J., Romestand, B., 2004. Insights into the anti-microbial defense of marine invertebrates: the penaeid shrimps and the oyster Crassostrea gigas. Immunological Reviews 198, 149-168. 
Baltimore, D., Beg, A.A., 1995. DNA-Binding proteins - A butterfly flutters by. Nature 373 (6512), 287-288.

Bettencourt, R., Asha, H., Dearolf, C., Ip, Y.T., 2004. Hemolymph-dependent and independent responses in Drosophila immune tissues. Journal of Cellular Biochemistry $92,84-49$.

Braissant, O., Wahli, W., 1998. A simplified in situ hybridization protocol using nonradioactively labelled probes to detect abundant and rare mRNAs on tissue sections. Biochemica 1, 10-16.

Campa-Cordova, A.I., Hernandez-Saavedra, N.Y., De Philippis, R., Ascencio, F., 2002. Generation of superoxide anion and SOD activity in haemocytes and muscle of American white shrimp (Litopenaeus vannamei) as a response to beta-glucan and sulphated polysaccharide. Fish and Shellfish Immunology 12 (4), 353-66.

Colaço, A., Santos, R.S., 2003. LABHORTA, A Land-based laboratory for vent studies. P. 36 in R.S. Santos, J. Escartín, A. Colaço and A. Adamczewska (Eds). Towards planning of sea-floor observatory programs for the MAR region (Proceedings of the II MoMar Workshop). Arquipélago, Life and Marine Sciences. Supplement 3: XII-64 pp.

Charlet, M., Chernysh, S., Philippe, H., Hetru, C., Hoffmann, J. A., Bulet, P., 1996. Innate immunity. Isolation of several cysteine-rich antimicrobial peptides from the blood of a mollusc, Mytilus edulis. Journal of Biological Chemistry 271, 21808-13. 
Distel, D.L., Lee, H.K.W., Cavanaugh, C.M., 1995. Intracellular coexistence of methanotrophic and Thioautotrophic bacteria in a hydrothermal vent mussel. Proceedings of the National Academy of Sciences of the United States of America 92 (21), 9598-9602.

Duperron, S., Bergin, C., Zielinski, F., Blazejak, A., Pernthaler, A., McKiness, Z.P., DeChaine, E., Cavanaugh, C.M., Dubilier, N., 2006. A dual symbiosis shared by two mussel species, Bathymodiolus azoricus and Bathymodiolus puteoserpentis (Bivalvia: Mytilidae), from hydrothermal vents along the northern Mid-Atlantic Ridge. Environmental Microbiology 8 (8), 1441-47

Escoubas, J. M., Briant, L., Montagnani, C., Hez, S., Devaux, C., Roch, P., 1999. Oyster IKK-like protein shares structural and functional properties with its mammalian homologues. FEBS letters 453, 293-298.

Felsenstein, J., 1985. Confidence limits on phylogenies: An approach using the bootstrap. Evolution 39, 783-791.

Fiala-Medioni, A., Felbeck, H., 1990. Autotrophic processes in invertebrate nutrition: Bacterial symbiosis in bivalve molluscs. in Animal Nutrition and Transport Processes. 1. Nutrition in Wild and Domestic Animals. Mellinger, J. (ed). Comparative Physiology vol 5, 49-69. 
Fiala-Medioni, A., McKiness, Z.P., Dando, P., Boulegue, J., Mariotti, A., Alayse-Danet, A.M., Robinson, J.J., Cavanaugh, C.M., 2002. Ultrastructural, biochemical, and immunological characterization of two populations of the mytilid mussel Bathymodiolus azoricus from the Mid-Atlantic Ridge: evidence for a dual symbiosis. Marine Biology 141 (6), 1035-1043.

Ghosh, S., May, M.J., Kopp, E.B., 1998. NF-кB and Rel proteins: evolutionarily conserved mediators of immune responses. Annual Review of Immunology 16, 225260.

Gourdon, I., Guerin, M.C., Torreilles, J., Roch, P., 2001. Nitric oxide generation by hemocytes of the mussel Mytilus galloprovincialis. Nitric Oxide, 5(1): 1-6

Gross, P. S., Bartlett, T. C., Browdy, C. L., Chapman, R. W. \& Warr, G. W., 2001. Immune gene discovery by expressed sequence tag analysis of hemocytes and hepatopancreas in the Pacific White Shrimp, Litopenaeus vannamei, and the Atlantic White Shrimp, L-setiferus. Developmental and Comparative Immunology 25, 565-577.

Gueguen, Y., Cadoret, J., Flament, D., Barreau-Roumiguiere, C., Girardot, A., Garnier, J., Hoareau, A., Bachere, E., Escoubas, J., 2003. Immune gene discovery by expressed sequence tags generated from hemocytes of the bacteria-challenged oyster, Crassostrea gigas. Gene Jan 16, 139-45. 
Gustafson, R.G., Turner, R.D., Lutz, R.A., Vrijenhoek, R.C., 1998. A new genus and five new species os mussels (Bivalvia, Mytilidae) from deep-sea sulphide/hydrocarbon seeps in the Gulf of Mexico. Malacologia 40, 63-112.

Hoffmann, J.A., Reichhart, J. M., 2002. Drosophila innate immunity: an evolutionary perspective. Nature Immunology 3, 121-126.

Hose, J. E., 1994. Large-Scale Genotoxicity Assessments in the Marine-Environment. Environmental Health Perspectives 102, 29-32.

Hubert, F., VanderKnaap, W., Noel, T., Roch, P., 1996a. Cytotoxic and antibacterial properties of Mytilus galloprovincialis, Ostrea edulis and Crassostrea gigas (bivalve molluscs) hemolymph. Aquatic Living Resources 9, 115-124.

Hubert, F., Noel, T., P. Roch, P., 1996b. A member of the arthropod defensin family from edible Mediterranean mussels (Mytilus galloprovincialis). European Journal of Biochemistry 240, pp 302-306.

Kadar, E., Bettencourt, R., Costa, V., Santos, R.S., Lobo-da-Cunha, A., Dando, P., 2005. Experimentally induced endosymbiont loss and re-acquirement in the hydrothermal vent bivalve Bathymodiolus azoricus. Journal of Experimental Marine Biology and Ecology 318, 99-110. 
Kumar S., Tamura, K., Nei, M., 2004. MEGA3: Integrated software for Molecular Evolutionary Genetics Analysis and sequence alignment. Briefings in Bioinformatics 5, $150-163$.

Leclerc, V., Reichhart, J. M., 2004. The immune response of Drosophila melanogaster. Immunological Reviews 198, 59-71.

Montagnani, C., Kappler, C., Reichhart, J., Escoubas, J., 2004. Cg-Rel, the first Rel/NFkappaB homolog characterized in a mollusk, the Pacific oyster Crassostrea gigas. FEBS letters 561, 75-82.

Nei, M., Kumar, S., 2000. Molecular Evolution and Phylogenetics. Oxford University Press, New York

Saitou, N., Nei, M., 1987. The neighbour-joining method: A new method for reconstructing phylogenetic trees. Molecular Biology and Evolution 4, 406-425.

Santos, S.R., Colaço, A., Christiansen, S., (Eds) 2003. Planning the Management of Deep-sea hydrothermal Vent Fields MPA in the Azores triple junction (Proceedings of the workshop). Arquipélago, Life and Marine Sciences. Supplement 4: xii-70

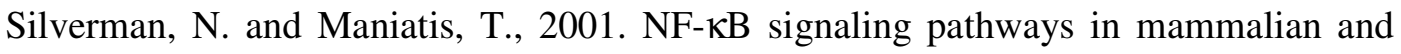
insect innate immunity. Genes \& Dev. 15: 2321-2342. 
Tanguy, A., Guo, X. M. and Ford, S. E., 2004. Discovery of genes expressed in response to Perkinsus marinus challenge in Eastern (Crassostrea virginica) and Pacific (C-gigas) oysters. Gene 338, 121-131.

Thompson, J.D., Gibson, T.J., Plewniak, F., Jeanmougin. F., Higgins, D.G., 1997. The Clustal X windows interface: flexible strategies for multiple sequence alignment aided by quality tools. Nucleic Acids Research 24, 4876-4882.

Vaseeharan B., Lin Y.C., Ko C.F., Chen J.C., 2006. Cloning and characterisation of a serine proteinase from the haemocytes of mud crab Scylla serrata. Fish and Shellfish Immunology 21(1), 20-31.

Von Cosel, R., Comtet, T., Krylova, E.M., 1999. Bathymodiolus (Bivalvia : Mytilidae) from hydrothermal vents on the Azores triple junction and the Logatchev hydrothermal field, Mid Atlantic Ridge. Veliger 42, 218-248

Wootton, E.C., Dyrynda, E.A., Ratcliffe, N.A., 2003. Bivalve immunity: comparisons between the marine mussel (Mytilus edulis), the edible cockle (Cerastoderma edule) and the razor-shell (Ensis siliqua). Fish \& Shellfish Immunology 15(3), 195-210.

Wootton, E.C., Pipe, R.K., 2003. Structural and functional characterisation of the blood cells of the bivalve mollusc, Scrobicularia plana. Fish \& Shellfish Immunology 15, 249-262 
FIGURE LEGENDS

Fig.1.A. Immunostimulation of hemocytes. Freshly withdraw hemocytes from Bathymodiolus azoricus were incubated with different pathogen associated molecular patterns, (PAMPs) suspensions as described in Methods and Materials. Hemocytes were incubated in Phosphate Buffered Saline (PBS) zymosan, glucan, peptidoglycan, lipopolysaccaride and phorbol-12-myristate-13-acetate suspensions for $15 \mathrm{~min}$ after which, cell morphology was observed and images captured under light microscopy with a Dialux 20 microscope (Leitz-Wetzlar, 20X and 40X objectives) and a color digital camera (Evolution LC, Media Cybernetics). During our experiments the majority of hemocytes observed corresponded to granulocytes (arrow heads). Immunostimulation was recorded as hemocytes exhibited philopodia extensions and intense degranulation when incubated with zymosan, glucan and peptidoglycan. In contrast no visible cell morphology alteration was observed when hemocytes were incubated with LPS or PMA (blue arrow heads). During control experiments hemocytes incubated in PBS maintained their cell integrity and morphology (White arrow heads).

Fig 1.B. Generation of superoxide by hemocytes of Bathymodiolus azoricus. Hemocytes were exposed to different commercially available substances of microbial origin and the subsequent production of $\mathrm{O}_{2}{ }^{-}$, monitored by spectrophotometry $(630 \mathrm{~nm})$. Results are from 4 experiments using hemocytes from different preparations and values are shown as mean \pm S.E.M.

Fig. 2. Antibacterial activity in Bathymodiolus azoricus gill and hemocyte homogenates. Gill $(\mathrm{G})$ and hemocyte $(\mathrm{H})$ homogenates were prepared as described in Methods and 
Materials and tested for their naïve antibacterial activity using standard Luria-Bertani (LB) plates overlaid with a top LB-agar layer containing one of the following bacterial strains: Gram positive bacteria, Micrococcus luteus, Bacillus subtilis and Staphylococcus aureus and gram negative bacteria, Enterobacter cloacae, Escherichia coli, Pseudomonas aeruginosa,. Bacterial growth inhibition zones were visualized in plates where Micrococcus luteus, Bacillus subtilis and Enterobacter cloacae were seeded. The results demonstrate the inherent property of gill tissues and to some extent hemocytes homogenates to exhibit antibacterial activity against gram negative and positive bacteria.

Fig. 3. Molecular identification of immune genes by Reverse Transcriptase-Polymerase Chain Reaction (RT-PCR)

Total RNA was extracted from gills of Bathymodiolus azoricus and Mytilus galloprovincialis according to Methods and Materials and used as template for DNA amplification. After reverse transcription of RNA into cDNA, degenerated and sequence-specific primers aimed at targeting immune genes in Bathymodiolus, Mytilus, Mercenaria (data not shown) and Ruditapes (data not shown) were used in Polymerase chain reactions (PCR). PCR amplicons corresponding to successful amplifications of the REL Homology domain (RHD) (white arrow heads) and mytilin gene (blue arrow head), are shown. Lane 1) Bathymodiolus azoricus PCR amplicon obtained with RHD degenerated primers; lane 2) Bathymodiolus azoricus PCR amplicon obtained with RHD sequence-specific primers; lane 3) Mytilus galloprovincialis PCR amplicon obtained with same RHD sequence-specific primers as in 2; lane 4) Bathymodiolus azoricus PCR amplicon obtained with mytilin sequence-specific primers based on the Mytilus galloprovincialis mytilin gene and lane 5) Bathymodiolus azoricus PCR 
amplicon obtained with defensin sequence-specific primers based on the Mytilus galloprovinciallis defensin gene. While the RHD and mytilin nucleotide identity was confirmed by sequencing analyses, the putative defensin PCR amplicon could not be confirmed by nucleotide sequencing.

Fig 4. A. Rel Homology Domain (RHD) amino acid sequences aligned with ClustalX (see Methods and Materials for alignment parameters). Different shading levels emphasize the degree of amino acid conservation in each column in the alignment: Black for $100 \%$ conservation; dark grey for $80 \%$ or greater conservation; light grey for $60 \%$ or greater conservation.

Fig 4. B. Neighbor-joining tree constructed from the Rel Homology Domain amino acid sequences. Numbers above internal branches indicate bootstrap values out of 1000 replicates (only if greater than 50\%).

Fig. 5. Expression of NF- $\mathrm{KB}$ transcription factor and mytilin messengers in whole mount preparations of gill tissues

The presence of Rel/Nuclear Factor- $\mathrm{KB}$ and mytilin transcripts was analyzed in in-situ hybridization experiments using Polymerase Chain Reaction-based cDNA products (probes) corresponding to the Rel homology domain (RHD) and the mytilin gene. PCR products were labeled with biotin and used as probes to target respective transcripts. Mytilin and putative RHD containing transcripts were identified in hemocytes (red arrow heads) located in gill filament epithelium or in between two coalescent unicellular layers of endothelial cells (upper and middle panels, respectively). cDNA probe corresponding to an irrelevant PCR product was used in control experiments. Broken 
circular red lines indicate the specialized endothelial (bacteriocyte) cell boundary (bottom panel). Original objective magnifications are indicated.

Fig. 6. Expression of NF- $\mathrm{KB}$ transcription factor and mytilin messengers in paraffinembedded sections of gill tissues.

Mytilin (B) and putative Rel Homology Domain (RHD) containing transcripts (C) were identified in hemocytes located in gill filaments, in between two coalescent unicellular layers (lumen) of endothelial cells (black arrow heads). Hematoxylin and Eosin staining of gill filaments showing the presence of hemocytes is indicated. (A, black arrow heads). Original objective magnifications are shown. 


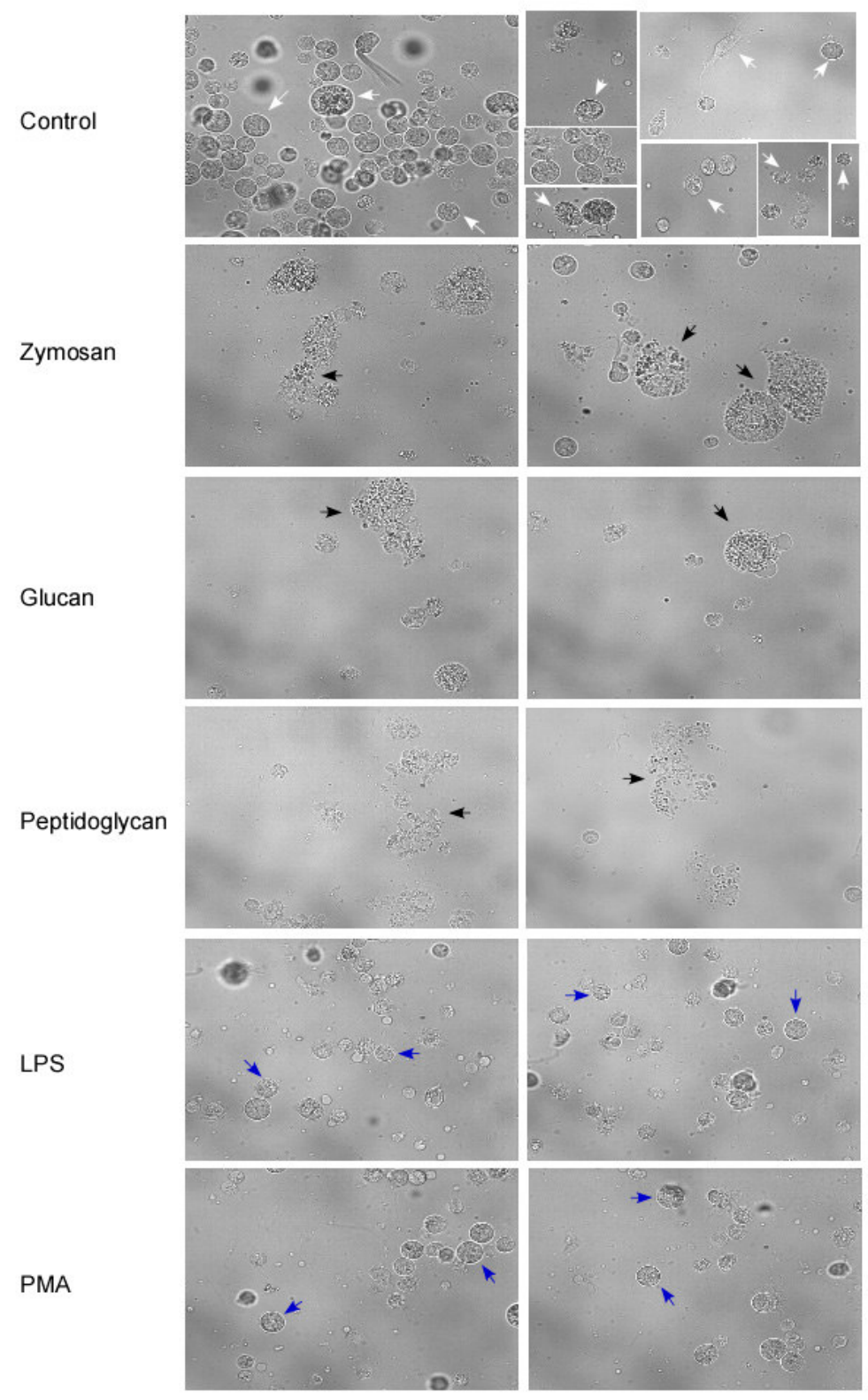

Fig 1A Bettencourt et al 2006 


\section{ACCEPTED MANUSCRIPT}

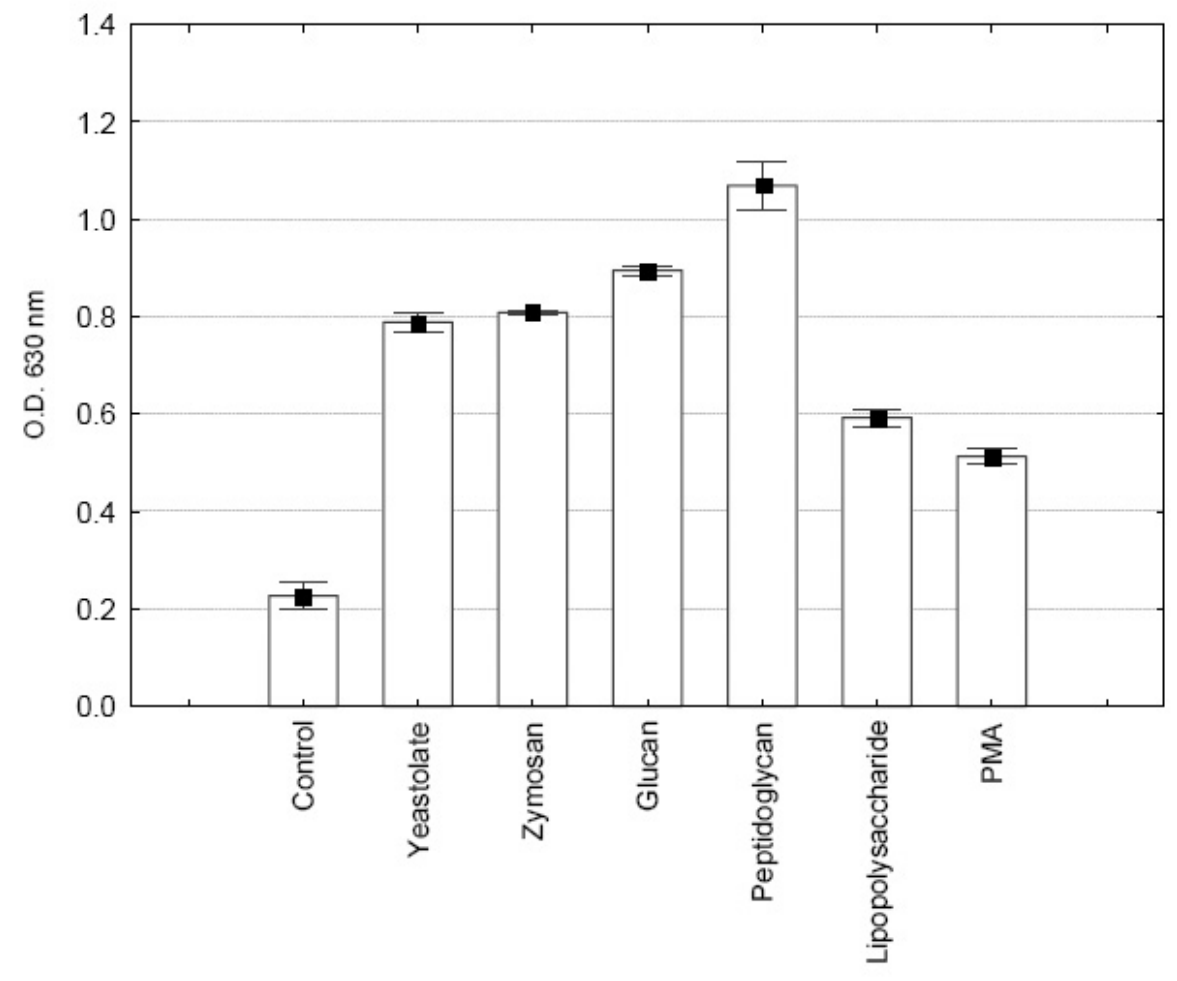

- Mean $\pm \pm \mathrm{SE}$

Fig. 1.B Bettencourt et al 2006 

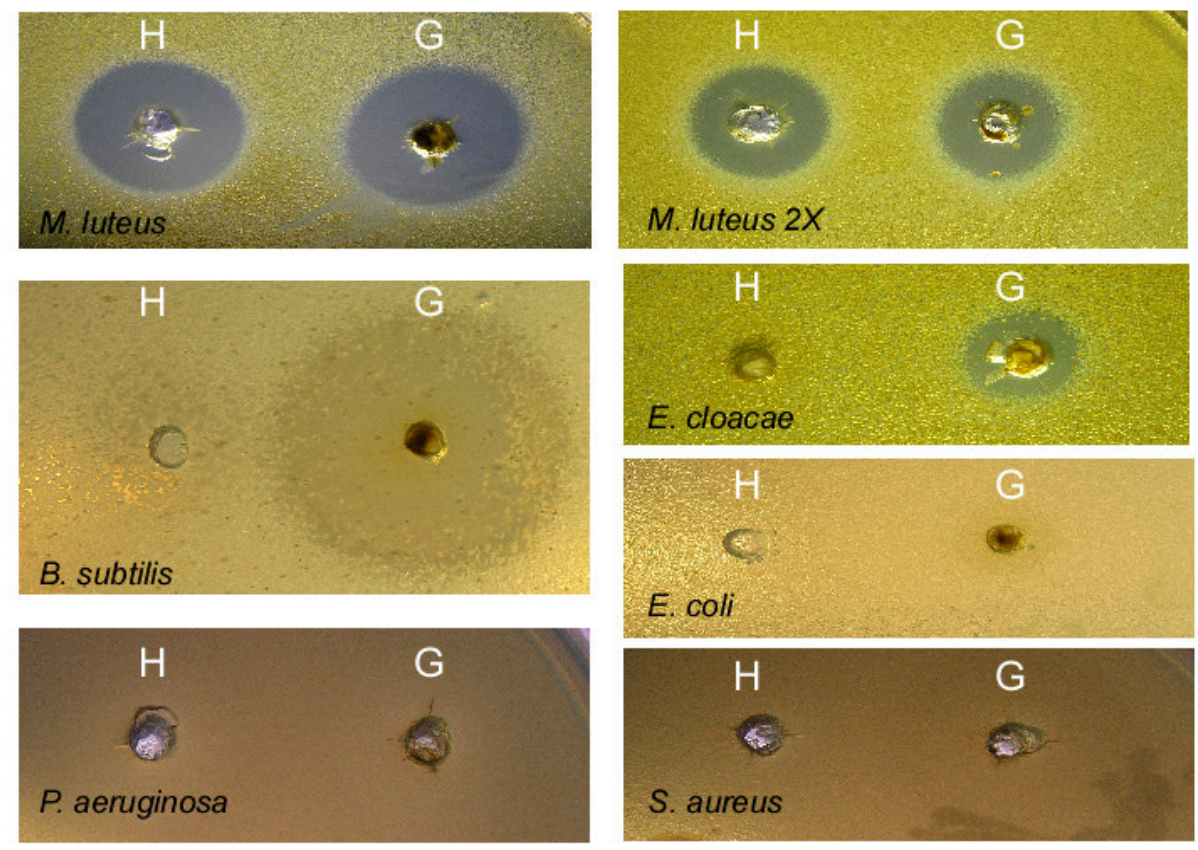

Fig 2 Bettencourt et al. 2006 


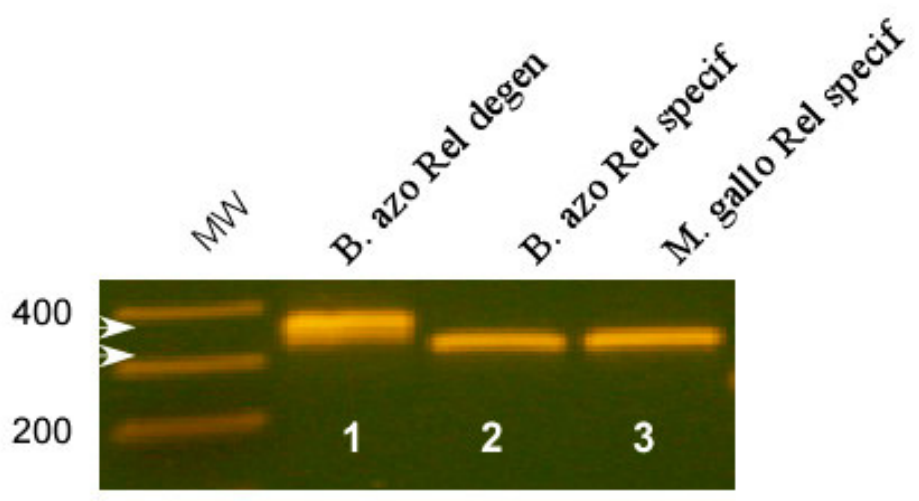

Fig 3 Bettencourt et al 2006 


\section{ACCEPTED MANUSCRIPT}

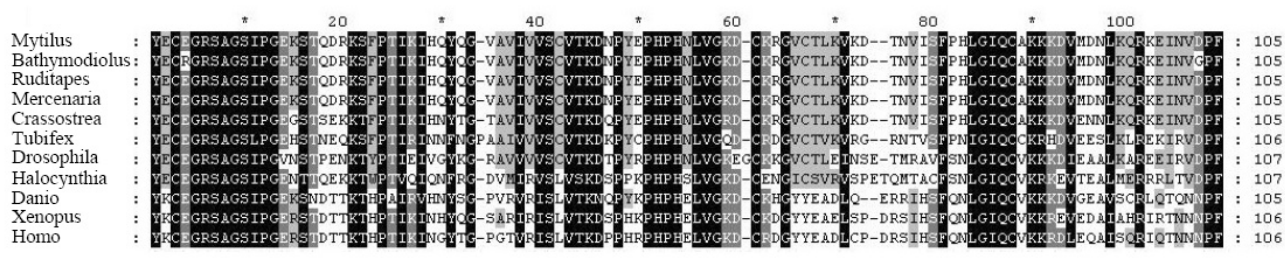

Fig 4A Bettencourt et al. 2006 


\section{ACCEPTED MANUSCRIPT}

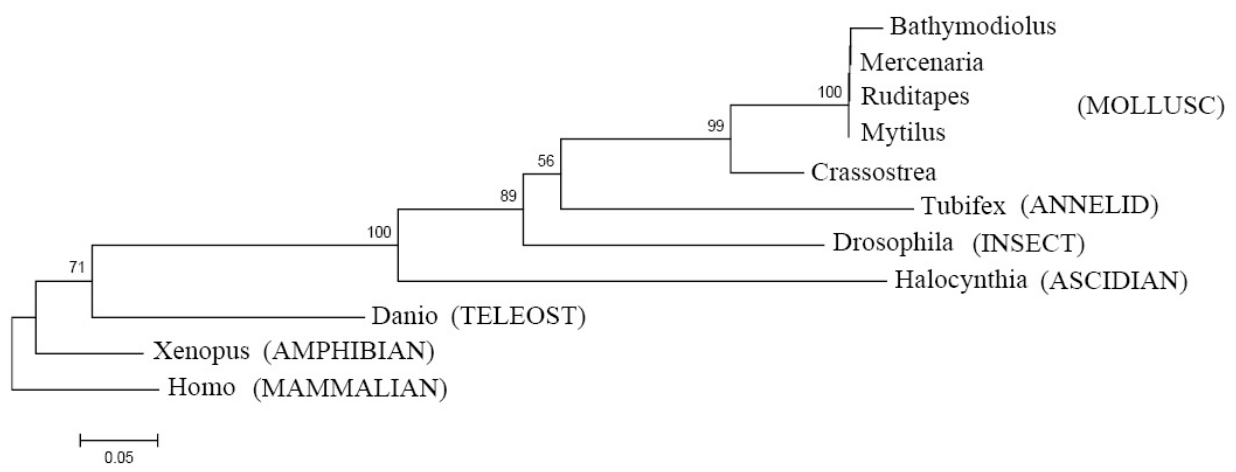

Fig 4B Bettencourt et al 2006 


\section{ACCEPTED MANUSCRIPT}
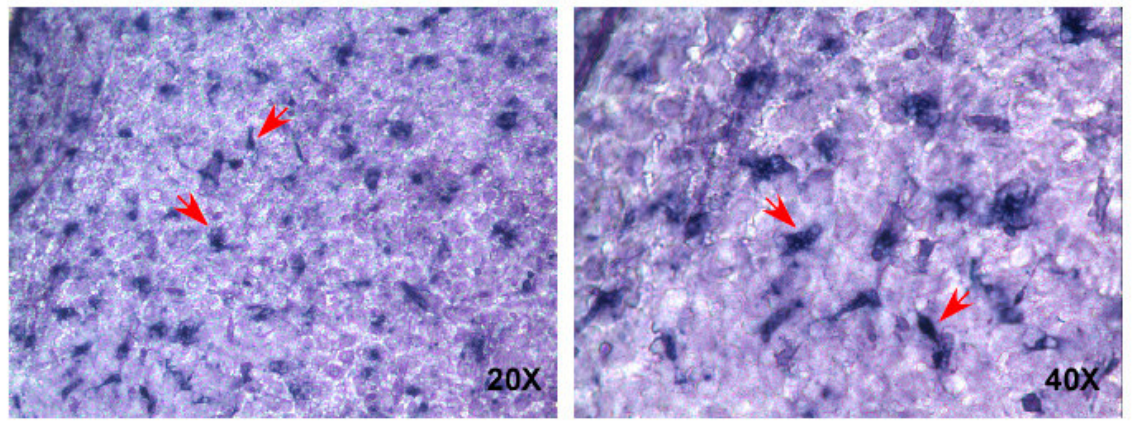

\section{Mytilin}
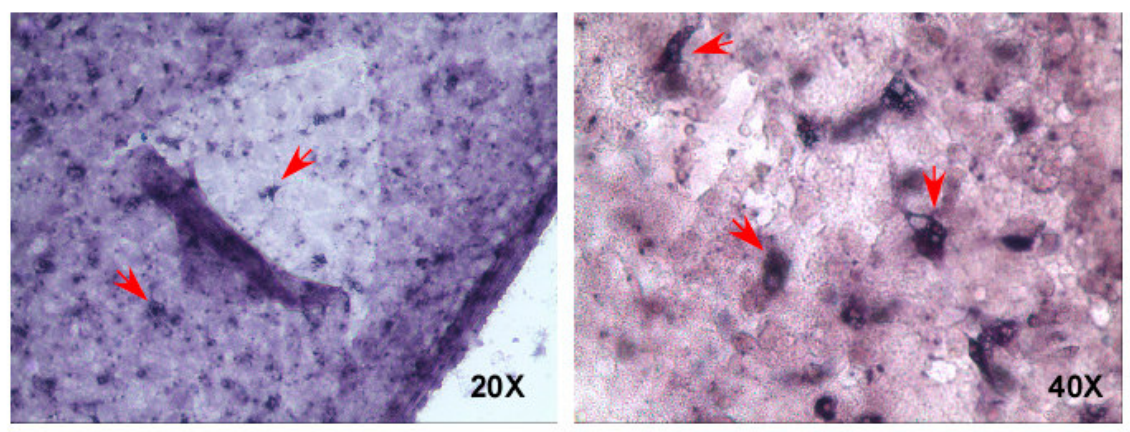

Rel
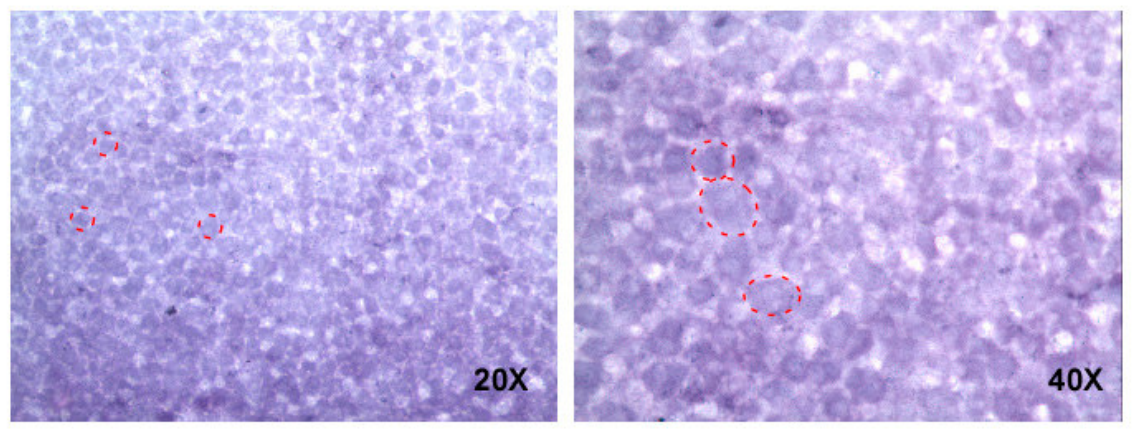

Control

Fig 5 Bettencourt et al 2006 


\section{ACCEPTED MANUSCRIPT}
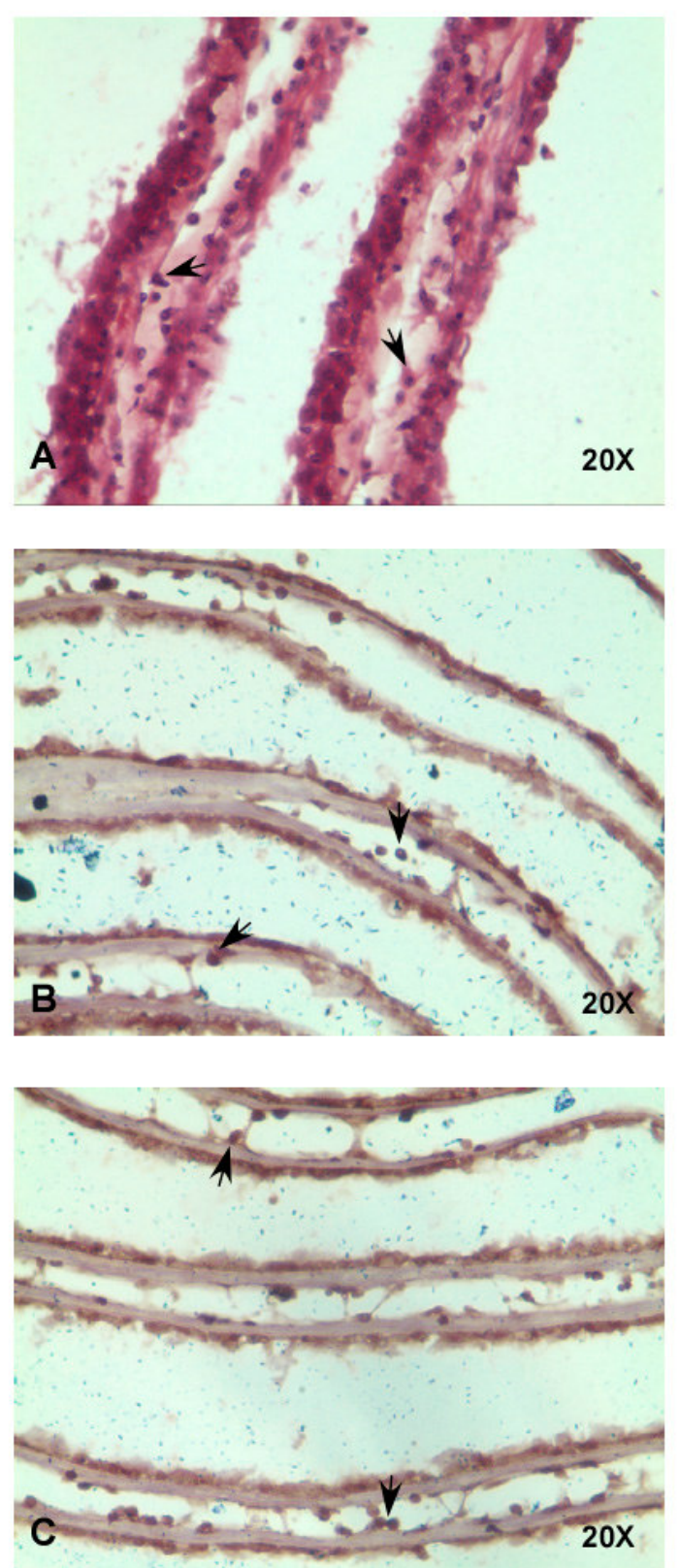

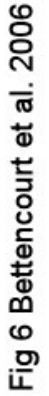

